ISSN 1392-3196 / e-ISSN 2335-8947

Zemdirbyste-Agriculture, vol. 108, No. 3 (2021), p. 241-246

DOI 10.13080/z-a.2021.108.031

\title{
Productivity potential of three tetraploid ryegrass cultivars and their mixture in new swards with clovers
}

\author{
Gintare ŠIDLAUSKAITĖ, Monika TOLEIKIENĖ, Žydrè KADŽIULIENĖ \\ Lithuanian Research Centre for Agriculture and Forestry, Institute of Agriculture \\ Instituto 1, Akademija, Kèdainiai distr., Lithuania \\ E-mail: gintare.sidlauskaite@lammc.lt
}

\begin{abstract}
Perennial ryegrass (Lolium perenne L.) is cultivated in many countries for its high yield and good quality forage. Its cultivars have specific functional traits, such as phenology, growth habit and rate, which affect the competitiveness and productivity of mixtures. The cultivation of new cultivars of perennial ryegrass or mixtures of cultivars in swards is one of the complementary measures to improve the condition of swards.

The study was aimed to determine the productivity potential of three newer, less investigated Lithuanian perennial ryegrass (Lolium perenne L.) cultivars 'Elena DS', 'Raminta', 'Verseka', and cultivar mixtures in single-species swards and in mixtures with legumes - white and red clover. The experiment was set up in the central part of Lithuania in the Nemoral climate zone. Mineral fertilisers were not used for the mixtures with legumes, singlespecies crops were fertilised with $\mathrm{N}_{150} \mathrm{~kg} \mathrm{ha}^{-1} \mathrm{yr}^{-1}$. Over the two experimental years, the average dry matter yield of perennial ryegrass was $8.00 \mathrm{t} \mathrm{ha}^{-1}$ for the 'Elena DS', $7.4 \mathrm{tha}^{-1}$ for 'Verseka', $6.9 \mathrm{t} \mathrm{ha}^{-1}$ for 'Raminta' and $7.4 \mathrm{t} \mathrm{ha}^{-1}$ for the cultivar mixture. In the $1^{\text {st }}$ year of sward use, the productivity of the perennial ryegrass cultivars did not differ significantly. In the $2^{\text {nd }}$ year, the productivity of 'Elena DS' was significantly higher compared with that of the other cultivars cultivated in single-species crops. The influence of functional traits of the cultivars was significant in the first year of cultivation and persisted in single-species swards but not in mixtures from the second year onwards. The plants of the cultivar 'Elena DS' allowed the development of clover in the mixture, resulting in an increase in herbage productivity and crude protein content.

The results of the experiment suggest that a mixture of perennial ryegrass cultivars can be used in swards, as a similar dry matter yield was recorded compared to a single-cultivar swards. However, the benefits of swards may vary from season to season, and more research is needed to assess the impact of a mixture of cultivars on grass productivity and quality with ageing of swards and accumulation in different environmental conditions.
\end{abstract}

Key words: dry matter yield, Lolium perenne, red clover, species richness, white clover.

\section{Introduction}

Across Europe, climate change could pose significant challenges for food production and ecosystem services provided by swards, but may also imply some opportunities (Foley et al., 2011; Weigelt et al., 2020) Climate change can increase sward productivity if soil moisture is not limiting (Zandalinas el at., 2017; Ergon et al., 2018; Yates et al., 2019).

Perennial ryegrass (Lolium perenne $\mathrm{L}$.) is the most widely used forage species in cool-temperate agricultura regions (McDonagh et al., 2016). Perennial ryegrass has been cultivated in Europe for many years because of its high yield and good forage quality. It is one of the most valuable grasses and is the main component of swards (Nekrošas, Kemešytè, 2007; Cosentino et al., 2018), thus research of different cultivars is very relevant. In other countries, especially southern ones, ryegrass is grown in single-species swards, and in Lithuania and neighbouring countries it is more often cultivated in mixtures with legumes and other grasses. So far studies have focused on the overall productivity of swards and their forage value as well as how different plant species can help each other in a mixture. However, only a few cultivars of ryegrass have been studied in mixtures. The intensity of plant growth varies and depends on different types of stress (Finn et al., 2018), which may affect the condition of swards.

The development of new cultivars that are more resistant to adverse environmental conditions is increasing Perennial ryegrass provides a cost-effective forage species. Vegetative persistence is an important trait for decreasing costs of pasture establishment and maintaining herbage growth and survival without reseeding. Vegetative persistence is uncertain because of a paucity of long-term trials to observe the complex interactions between plant genotype and changing environmental conditions. Over time in a long-term trial, a shift in the genetic traits of a cultivar could occur as plants with genetically enhanced persistence traits could have stronger competitive features (Bothe et al., 2018). Results of studies show that perennial ryegrass cultivars differ in tolerance of stressful conditions such as drought and cold. Tetraploid genotypes are more tolerant of stressful growth conditions than diploid ones. Tetraploids are also characterized by better spring growth, higher dry matter yield and better regrowth after cutting (Kemesyte et al., 2017).

Limitations to land availability with increasing environmental requirements to reduce greenhouse gas emissions (Schmitz et al., 2012), and $\mathrm{N}$ losses to ground water are placing increased pressure on grass-based production systems to provide additional quantities of highquality forage. The ability to increase forage yield through increased fertiliser inputs is limited (Crews, Peoples, 2005; Schaub et al., 2020 a). Thus, increased performance must be achieved by other means, and one of the most important avenues is perennial ryegrass cultivation in combination with other plant species (Li et al., 2015). Swards of different composition not only led to an increase in biodiversity but

Please use the following format when citing the article:

Šidlauskaitė G., Toleikienė M., Kadžiulienẻ Ž. 2021. Productivity potential of three tetraploid ryegrass cultivars and their mixture in new swards with clovers. Zemdirbyste-Agriculture, 108 (3): 243-250. DOI 10.13080/z-a.2021.108.031 
also to enhanced environmental function (Finn et al., 2018; Schaub et al., $2020 \mathrm{~b}$ ).

There are also important complicating factors such as plant competition and other plant interactions (Finn et al., 2013), perennial plants' growth habits and seasonal productivity patterns (Porter et al., 2014; Helgadóttir et al., 2018). However, over the last decade it has been shown in the ecology literature that species diversity increases yield stability (Finger, Buchmann, 2015; Baral et al., 2019; McDonagh et al., 2020). The use of nutrient resources is a very important factor (Toleikiene et al. 2020) in terms of competition (Dabkevičienè el al., 2017) and compatibility of species and their quality (Schaub et al., $2020 \mathrm{~b}$ ), productive growth in the same place a the same time. Biological nitrogen-fixing legumes and mineral nitrogen fertilisers were used to meet the nutrient demand in the swards.

The aim of the study was to determine the productivity potential of three newer, less investigated perennial ryegrass (Lolium perenne L.) cultivars 'Elena DS', 'Raminta', 'Verseka', and cultivar mixture in single-species swards and in mixtures with legumes - white and red clover. The productivity of the tested cultivars and cultivar mixture can show very significant differences in dry matter yield. It is important to select cultivars adapted to growing under local conditions.

\section{Materials and methods}

Experimental site description. The field experiment was established in 2018 and will be continued until 2022 at the Lithuanian Research Centre for Agriculture and Forestry, located in Akademija

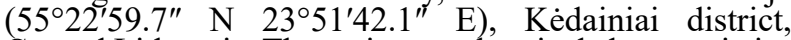
Central Lithuania. The main agrochemical characteristics of the soil arable $(0-25 \mathrm{~cm})$ layer were measured prior to undertaking the experiment in 2018 (Table 1).

The soil of the experimental site was loamy Endocalcaric Epigleyic Cambisol (WRB, 2014). The characteristics of the soil arable $(0-25 \mathrm{~cm})$ layer were as follows: neutral soil acidity $\mathrm{pH} 6.9$ and relatively high soil organic carbon $1.76 \%$ with a high content of plant available phosphorus (P) $98 \mathrm{mg} \mathrm{kg}^{-1}$ and potassium (K) $144 \mathrm{mg} \mathrm{kg}^{-1} .2018$ was the year of sowing, $2019-1^{\text {st }}$ and $2020-2^{\text {nd }}$ year of sward use. In the spring of 2018 , NPK fertilisers were applied at a rate of N-P-K $5-20.5-36 \mathrm{~kg}$ $\mathrm{ha}^{-1}$. In 2019 and 2020, single-species swards received $\mathrm{N}$ fertiliser at $150 \mathrm{~kg} \mathrm{ha}^{-1} \mathrm{yr}^{-1}: \mathrm{N}_{60}$ in spring, $\mathrm{N}_{45}$ after the $1^{\text {st }}$ and $\mathrm{N}_{45}$ after the $2^{\text {nd }}$ cut. The swards were cut 4 and 5 times in 2019 and 2020, respectively. Mixtures of grass and legume were not fertilised. The site was managed with no extra irrigation, no pesticides were used.

Table 1. The main agrochemical soil characteristics before the experiment

\begin{tabular}{cccccc}
\hline $\begin{array}{c}\text { Soil depth } \\
\mathrm{cm}\end{array}$ & $\begin{array}{c}\mathrm{pH}_{\mathrm{KCl}} \\
\text { suspension }\end{array}$ & $\begin{array}{c}\text { Phosphorus (P) } \\
\mathrm{mg} \mathrm{kg}^{-1}\end{array}$ & $\begin{array}{c}\text { Potassium }(\mathrm{K}) \\
\mathrm{mg} \mathrm{kg}^{-1}\end{array}$ & $\begin{array}{c}\mathrm{C}_{\text {org }} \\
\%\end{array}$ & $\begin{array}{c}\text { Total nitrogen } \\
(\mathrm{N}) \%\end{array}$ \\
\hline $0-10$ & 6.9 & 101 & 179 & 1.87 & 0.245 \\
$10-25$ & 6.8 & 94 & 109 & 0.248 & 1.64 \\
\hline
\end{tabular}

Experimental design, treatments and measurements. In this experiment, newer, less investigated Lithuanian cultivars of perennial ryegrass were used. The experiment was laid out in a randomized complete block design with four replications. Each plot was $1.5 \mathrm{~m}$ wide and $10.0 \mathrm{~m}$ long. The investigated plant species were as follows: perennial ryegrass (Lolium perenne L.) cultivars 'Elena DS' (G1). 'Raminta' (G2) and 'Verseka' (G3), seed rate $18 \mathrm{~kg}^{-1}$; ; legumes: white clover (Trifolium repens L.) cultivar 'Dotnuviai' (L1), seed rate $10 \mathrm{~kg} \mathrm{ha}^{-1}$ and red clover (Trifolium pratense L.) cultivar 'Sadūnai' (L2), seed rate $15 \mathrm{~kg} \mathrm{ha}^{-1}$. The cultivar 'Elena DS' was selected as a control treatment to assess the productivity of cultivars. The time of sowing was May 4, 2018.
Perennial ryegrass cultivars were sown in single-species swards, as a mixture of three ryegrass cultivars and in mixtures with white and red clovers. Single-species swards and mixtures with two and three plant species were sown in the experimental plots. The experiment included 8 treatments consisting of perennial ryegrass single-cultivar swards, cultivar mixture and mixtures with legumes: $1-\mathrm{G} 1,2-\mathrm{G} 2,3-\mathrm{G} 3,4-\mathrm{G} 1+\mathrm{G} 2+\mathrm{G} 3,5$ - L1/G1, 6 - L 1/G1+G2+G3,7 - L1+L2/G1, 8- L1+L2/ $\mathrm{G} 1+\mathrm{G} 2+\mathrm{G} 3$ (Table 2). Legume and grass ratio in the sown mixtures was 40:60.

All cuts were taken depending on the predominant plant species. Grass growth stage before cut was when flower head was enclosed in flag leaf sheath

Table 2. The composition of single-species swards and mixtures with legumes

\begin{tabular}{|c|c|c|c|c|c|c|c|c|c|c|}
\hline \multirow[b]{2}{*}{ Treatment } & \multirow[b]{2}{*}{$\mathrm{FG}$} & \multirow[b]{2}{*}{ SP-r } & \multirow{2}{*}{$\begin{array}{c}\text { FG of } \\
\text { grasses }\end{array}$} & \multirow{2}{*}{$\begin{array}{c}\text { FG of } \\
\text { legumes }\end{array}$} & \multicolumn{3}{|c|}{ Perennial ryegrass } & \multicolumn{3}{|c|}{ Clover } \\
\hline & & & & & 'Elena DS' & 'Raminta' & $\begin{array}{c}\text { 'Verseka' } \\
\text { G3 }\end{array}$ & $\begin{array}{c}\text { 'Dotnuviai' } \\
\text { L1 }\end{array}$ & $\begin{array}{l}\text { 'Sadūnai' } \\
\text { L2 }\end{array}$ & $\begin{array}{l}\text { N-level } \\
\mathrm{kg} \mathrm{ha}^{-1}\end{array}$ \\
\hline 1. G1 & 1 & 1 & 1 & & 1 & & & & & $\mathrm{~N}_{150}$ \\
\hline 2. G2 & 1 & 1 & 1 & & & 1 & & & & $\mathrm{~N}^{150}$ \\
\hline 3. $\mathrm{G} 3$ & 1 & 1 & 1 & & & & 1 & & & $\mathrm{~N}_{150}^{150}$ \\
\hline 4. $\mathrm{G} 1+\mathrm{G} 2+\mathrm{G} 3$ & 1 & 1 & 1 & & 0.33 & 0.33 & 0.33 & & & $\mathrm{~N}_{150}^{150}$ \\
\hline 5. L1/G1 & 2 & 2 & 0.6 & 0.4 & 0.6 & & & 0.4 & & $\mathrm{~N}^{50}$ \\
\hline 6. $\mathrm{L} 1 / \mathrm{G} 1+\mathrm{G} 2+\mathrm{G} 3$ & 2 & 2 & 0.6 & 0.4 & 0.2 & 0.2 & 0.2 & 0.4 & & $\mathrm{~N}_{0}^{0}$ \\
\hline 7. $\mathrm{L} 1+\mathrm{L} 2 / \mathrm{G} 1$ & 2 & 3 & 0.6 & 0.4 & 0.6 & & & 0.2 & 0.2 & $\mathrm{~N}_{0}^{0}$ \\
\hline 8. $\mathrm{L} 1+\mathrm{L} 2 / \mathrm{G} 1+\mathrm{G} 2+\mathrm{G} 3$ & 2 & 3 & 0.6 & 0.4 & 0.2 & 0.2 & 0.2 & 0.2 & 0.2 & $\mathrm{~N}_{0}^{0}$ \\
\hline
\end{tabular}

Note. FG - functional group, i.e., combination of forage species that comprise grasses and legumes; SP-r - species richness.

and not showing or only showing partly. Meanwhile, legume growth stage was start of flowering. The first yield of swards was taken 8 and 6 weeks after the start of vegetation in 2019 and 2020, respectively. All cuts were taken at the same time for all treatments. To determine the dry matter yield (DMY), samples of $1-1.5 \mathrm{~kg}$ fresh biomass were oven dried at $105^{\circ} \mathrm{C}$ temperature to a constant weight, also samples were taken while performing the sward botanical composition analysis for each cut. Plant chemical analysis was conducted to assess the quality of the swards. Determination of crude protein was done with a NIRS 6500 spectrometer (FOSS, Denmark) in dried grass biomass.

Climatic conditions. Lithuania is in a temperate climatic zone, where the mean annual air temperature is $6.9^{\circ} \mathrm{C}$ and the growing season lasts from 169 to 202 days The duration of plant vegetation in the $1^{\text {st }}$ year of sward use was 182 days (from April 7 to September 1, 2019), in the $2^{\text {nd }}$ year -217 days (from March 3 to September 10 , 2020 ). In the $2^{\text {nd }}$ year of sward growth, plant vegetation started earlier than in the $1^{\text {st }}$ year and ended later and was 35 days longer. The weather data were collected at the Dotnuva Meteorological Station located in Akademija, Kedainiai district using the temperature and rainfall sensors (Figure 1).

In the $1^{\text {st }}$ year of swards growth, at the beginning of vegetation, which was the beginning of April, there was a very dry period, when the amount of precipitation did not exceed $1 \mathrm{~mm}$. In the $2^{\text {nd }}$ year of swards growth, the beginning of vegetation was more favourable for grasses. Assessment of the agrometeorological conditions according to the values of the hydrothermal coefficient (HTC $<0.5$ ) showed that the prolonged very dry period in June of 2019 reached the indicators of a dangerous meteorological phenomenon, and in the middle of the month it reached the indicators of natural drought. Although the average annual temperature and precipitation varied slightly in both experimental years, the year 2020 was warmer and wetter. The climatic conditions in certain months of vegetation were observed, namely the temperature in April 2019 was 24\% higher with 9 times lower precipitation, and in June the temperature was $8 \%$ higher with 10 times lower precipitation. 


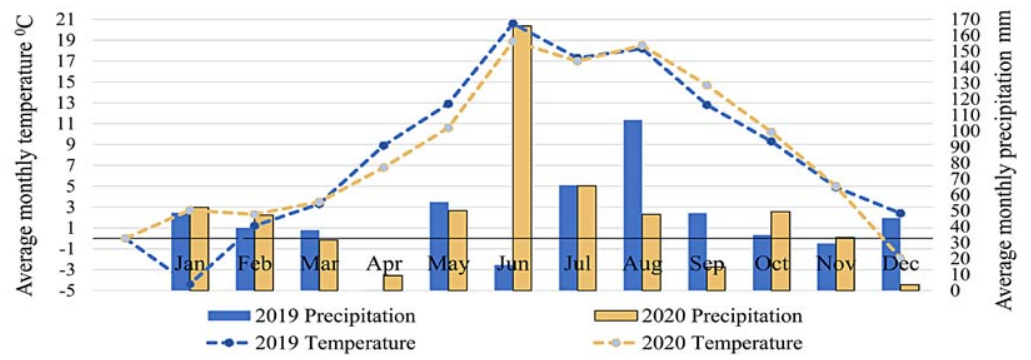

Figure 1. Meteorological conditions during the experimental years (2019 and 2020)

Statistical analysis. To analyse the effects of the treatment, an analysis of variance (ANOVA) was conducted. Significant differences between the experimental treatments were determined using Duncan's multiple range test at the $5 \%$ probability level $(p<0.05)$.

\section{Results}

Effects of a single cultivar or cultivar mixture of perennial ryegrass on annual DMY of swards. The obtained results showed differences between the cultivated perennial ryegrass cultivars; however, no significant differences $(p>0.05)$ were found between them in the $1^{\text {st }}$ year of sward use (Figure $2 \mathrm{~A}$ ). Comparing the tested cultivars of perennial ryegrass and considering that mineral $\mathrm{N}$ fertiliser was used in the first four treatments it was found that the highest annual yield was produced by the perennial ryegrass cultivar 'Elena DS', the yield of 'Verseka' was $1.5 \%$ lower and that of 'Raminta' $-5.2 \%$ lower. The yield of the mixture of perennial ryegrass cultivars was lower than that of single cultivar swards but not significantly. The annual DMY was significantly $(p<0.05)$ affected by the species composition of the sward. It was found that the DMY of a single cultivar or cultivar mixtures fertilised with mineral $N$ was $18 \%$ higher than that of mixtures of perennial ryegrass with legumes; however, significant difference was found in the swards with legumes.

The lowest annual DMY was determined in the ryegrass mixtures with white clover, significant differences were found compared to the other swards. When using one additional legume component, i.e., red clover, in a mixture with 'Elena DS', the DMY' of the sward increased by $19.5 \%$ and in the cultivar mixture the yield - by $16 \%$. When analysing the growth potential of plants in mixtures, it was observed that 'Elena DS' was more productive in mixtures with a legume component than in the cultivar mixture. It was found that the DMY of single-species swards increased by $9 \%$ and that of mixtures with a legume by $30 \%$ in the $2^{\text {nd }}$ year of sward use (Figure $2 B$ ).

The yield of 'Elena DS' mixture with white and red clover was the highest in the $2^{\text {nd }}$ year of sward use; its yield was $16 \%$ higher compared with that of 'Elena DS single cultivar sward fertilised with mineral $N$. Mineral $\mathrm{N}$ fertiliser was used to meet nutritional needs of single-species swards. The annual rate of $\mathrm{N} \mathrm{kg} \mathrm{ha}^{-1}$ fertiliser in the swards was equal to the effect of legumes, and no significant differences were found between the treatments. Averaged over the two experimental years, the DMY was significantly increased by plant diversity in the swards, but not all species had a significant effect on sward productivity: indeed, perennial ryegrass cultivar 'Elena DS' with white clover was $25 \%$ less productive than with white and red clover.

Botanical composition of the swards. A decrease in the number of perennial ryegrass plants was found in the swards with legumes. About $25 \%$ decrease of 'Elena DS' plants in the mixture with white clover was recorded in the $1^{\text {st }}$ year and $60 \%$ in the $2^{\text {nd }}$ year, while in the mixture with white and red clover the decrease amounted to $50 \%$ and $75 \%$, respectively. A similar decrease was observed also in the cultivar mixture. It was found that red clover had a greater effect on the sward productivity than white clover during both experimental years. The competition between plants is an important factor in the overall yield of swards. The competitive properties of red clover in mixtures were stronger than those of white clover, which is the reason why the number of white clover plants in mixtures with red clover decreased by $90 \%$. (Figure 3 ).

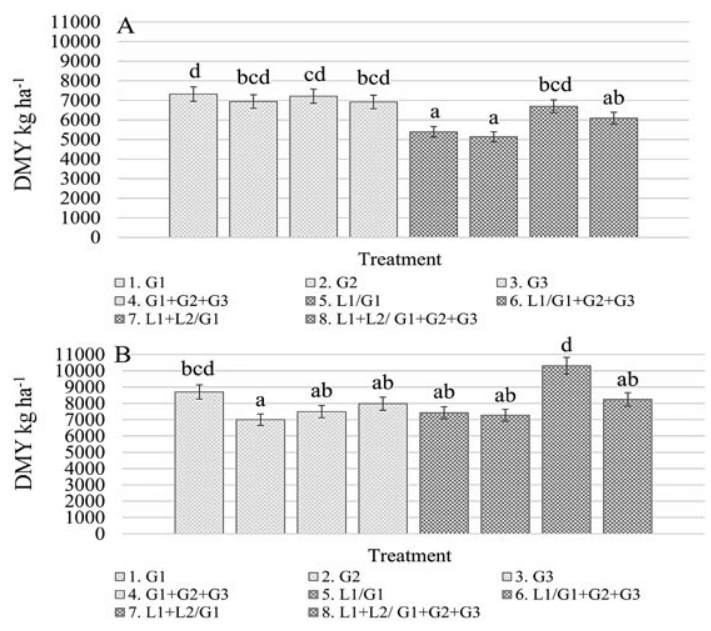

Note. Grasses: perennial ryegrass: G1 - 'Elena DS', G2 - 'Raminta', G3 - 'Verseka'; legumes: L1 - white clover 'Dotnuviai', L2 - red clover 'Sadūnai'; level of N fertiliser per year: 1-4 treatments $-\mathrm{N}_{150} \mathrm{~kg} \mathrm{ha}^{-1}, 5-8$ treatments $-\mathrm{N}_{0} \mathrm{~kg} \mathrm{ha}^{-1}$; different letters indicate significant differences between the treatments $(p<0.05)$

Figure 2. Annual dry matter yield (DMY) in the $1^{\text {st }}(\mathrm{A})$ and $2^{\text {nd }}(B)$ year of sward use

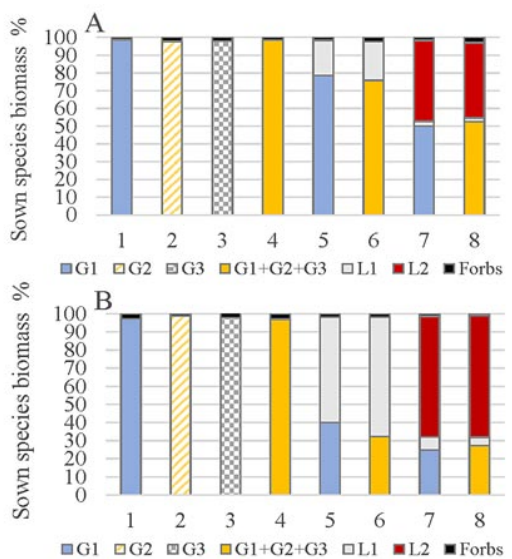

Treatments: $1-\mathrm{G} 1,2-\mathrm{G} 2,3-\mathrm{G} 3,4-\mathrm{G} 1+\mathrm{G} 2+\mathrm{G} 3,5-\mathrm{L} 1 / \mathrm{G} 1$, $6-\mathrm{L} 1 / \mathrm{G} 1+\mathrm{G} 2+\mathrm{G} 3,7-\mathrm{L} 1+\mathrm{L} 2 / \mathrm{G} 1,8-\mathrm{L} 1+\mathrm{L} 2 / \mathrm{G} 1+\mathrm{G} 2+\mathrm{G} 3$ explanation under Figure 2

Figure 3. Botanical composition of the swards in the $1^{\text {st }}$ (A) and $2^{\text {nd }}(B)$ year of sward use

Crude protein in herbage. The crude protein content was determined in the herbage of two most productive $\left(1^{\text {st }}\right.$ and $\left.3^{\text {rd }}\right)$ cuts. In both experimental years, a higher crude protein content was found in the $3^{\text {rd }}$ cut $-43-36 \%$, accordingly on average (Table 3 ). No significant differences were found between perennial ryegrass single cultivar swards. A similar amount of crude protein was also found in the mixture of cultivars. Perennial ryegrass 'Raminta' had better quality in the first cut, although it is the latest maturing cultivar. White and red clover in the mixtures significantly increased the amount of crude protein. 
Table 3. Crude protein content in the herbage of swards of different composition

\begin{tabular}{|c|c|c|c|c|c|c|}
\hline \multirow{3}{*}{ Treatment } & \multicolumn{6}{|c|}{ Crude protein content in dry matter yield \% } \\
\hline & \multicolumn{2}{|r|}{2019} & \multirow{2}{*}{ Mean } & \multicolumn{2}{|r|}{2020} & \multirow{2}{*}{ Mean } \\
\hline & $1^{\text {st }}$ cut & $3^{\text {rd }}$ cut & & $1^{\text {st }}$ cut & $3^{\text {rd }}$ cut & \\
\hline 1. G1 & $8.7 \mathrm{~ns}$ & $14.8 \mathrm{a}$ & $11.8 \mathrm{a}$ & $8.3 \mathrm{a}$ & $13.3 \mathrm{a}$ & $10.8 \mathrm{a}$ \\
\hline 2. G2 & $10.7 \mathrm{~ns}$ & $14.8 \mathrm{a}$ & $12.8 \mathrm{ab}$ & $9.2 \mathrm{ab}$ & $12.8 \mathrm{ab}$ & $11.0 \mathrm{a}$ \\
\hline 3. G3 & $8.9 \mathrm{~ns}$ & $15.3 \mathrm{ab}$ & $12.1 \mathrm{a}$ & $8.7 \mathrm{a}$ & $14.1 \mathrm{~b}$ & $11.4 \mathrm{a}$ \\
\hline 4. $\mathrm{G} 1+\mathrm{G} 2+\mathrm{G} 3$ & $9.3 \mathrm{~ns}$ & $15.5 \mathrm{ab}$ & $12.4 \mathrm{a}$ & $8.9 \mathrm{ab}$ & $12.8 \mathrm{a}$ & $10.9 \mathrm{a}$ \\
\hline 5. L1/G1 & $9.3 \mathrm{~ns}$ & $17.5 \mathrm{bcd}$ & $13.4 \mathrm{abcd}$ & $10.9 \mathrm{c}$ & $19.0 \mathrm{cde}$ & $15.0 \mathrm{~b}$ \\
\hline 6. $\mathrm{L} 1 / \mathrm{G} 1+\mathrm{G} 2+\mathrm{G} 3$ & $8.7 \mathrm{~ns}$ & $18.2 \mathrm{~cd}$ & 13.4 abcd & $10.5 \mathrm{bc}$ & $19.9 \mathrm{e}^{-}$ & $15.2 \mathrm{bcd}$ \\
\hline 7. $\mathrm{L} 1+\mathrm{L} 2 / \mathrm{G} 1$ & $10.5 \mathrm{~ns}$ & $18.5 \mathrm{~cd}$ & 14.5 bcd & $12.7 \mathrm{e}$ & $19.6 \mathrm{de}$ & $16.2 \mathrm{~d}$ \\
\hline 8. $\mathrm{L} 1+\mathrm{L} 2 / \mathrm{G} 1+\mathrm{G} 2+\mathrm{G} 3$ & $10.5 \mathrm{~ns}$ & $19.0 \mathrm{~d}$ & $14.7 \mathrm{~d}$ & $13.8 \mathrm{e}$ & $18.1 \mathrm{c}$ & $15.9 \mathrm{bcd}$ \\
\hline $\begin{array}{r}p \text {-value } \\
\text { between cuts }\end{array}$ & $p=0.17$ & $p=0.00$ & $p=0.01$ & $p=0.0$ & $p=0.00$ & $p=0.00$ \\
\hline
\end{tabular}

Explanation under Figure 2; ns - no significant difference

\section{Effects of perennial ryegrass single cultivar and} cultivar mixture on the seasonal production of $D M Y$. Mixture composition had different influence on the sward DMY and each component separately; however, the multispecies swards exerted greater influence on the yield than the use of mineral fertilisers. In two experimental years, significant differences were found in all cuts. In the $1^{\text {st }}$ year, the yield of the $2^{\text {nd }}$ cut was $94 \%$ lower compared with the annual yield. Meteorological conditions, especially low precipitation amount $(33 \mathrm{~mm}$, HTC $<0.5)$, which caused drought conditions, were a limiting factor for productive plant growth and proper nutrient uptake (Figure 4). Under unfavourable growth conditions, the multi-species swards produced significantly higher yield.

The data show that DMY was the highest in the $1^{\text {st }}$ cut i.e., $72 \%$ and $61 \%$ higher in 2019 and 2020 respectively, compared with the annual average. In the $1^{\text {st }}$ year of sward use, the lowest yield was in the $4^{\text {th }}$ cut, in the $2^{\text {nd }}$ year - in the $5^{\text {th }}$ cut. Higher yields were recorded in the second year of sward use. The yield of singlespecies crops, fertilised with mineral $\mathrm{N}$ fertiliser, increased by $9 \%$; meanwhile, the yield of multi-species swards increased by $30 \%$. The prolonged very dry period in the $1^{\text {st }}$ experimental year with indicators of the natural drought, affected perennial ryegrass cultivars. Ccultivars 'Elena DS', 'Raminta' and 'Verseka' had the highest DMY in the $1^{\text {st }}$ cut. This plant species is susceptible to drought, which highly affected the annual yield of the $1^{\text {st }}$ experimental year. Only traces of white clover were found in the $1^{\text {st }}$ year, but it increased by $80 \%$ in the $2^{\text {nd }}$ year; however, there were no significant differences compared with the other treatments. Meanwhile, red clover was productive, since the $1^{\text {st }}$ year of growth and its productivity increased by $60 \%$ in the $2^{\text {nd }}$ year. However, the swards with white and red clover with 'Elena DS' were the most productive in all cuts, except the $1^{\text {st }}$ cut.

\section{Discussion}

Perennial ryegrass cultivar effect on herbage yield. Swards cover a major share of the world's agricultural land area and are important for global food security. Because of the high yielding ability, perennial ryegrass is used in many countries, including Lithuania. However, changing climate challenges the existing perennial ryegrass cultivars to adapt to new growing conditions and maintain the yield (Finn et al., 2018; Komainda et al., 2020). In our experiment, newer, less investigated tetraploid perennia ryegrass cultivars, characterized by high yields, good feed quality and disease resistance, were used.

In two experimental years, the tetraploid perennial ryegrass cultivars demonstrated variation in their growth patterns. In the $1^{\text {st }}$ year of sward use, perennial ryegrass single-cultivar swards were more productive than the mixture of perennial ryegrass cultivars, but no significant differences were found between them. In the $2^{\text {nd }}$ year of use the cultivar mixture was more productive than the perennial ryegrass single cultivars 'Raminta' and 'Verseka'. Lowry et al. (2020) have reported that the effects of functional trait diversity within cultivar mixtures cannot always be predicted by the performance of cultivars in single-species crops. This may also depend on the synergy between varietal traits as well as on management practice (Tubritt et al., 2021).

The growth of the cultivar 'Raminta' lasts longer compared with that of the other cultivars, and the competitive aspects of the plants may also have contributed. The first harvest in the $1^{\text {st }}$ year of sward use showed that the yield of this cultivar was the lowest, which may have influenced the results of the $1^{\text {st }}$ year

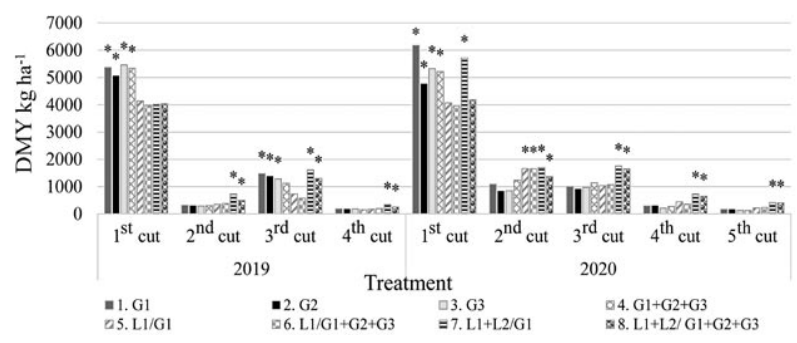

Explanation under Figure 2; * - indicate significant differences between the treatments $(p<0.05)$.

Figure 4. The dry matter yield (DMY) of swards during the experimental years

DMY of the cultivar mixture. The formed sward of the mixture of cultivars in the $2^{\text {nd }}$ year of use showed better yield than some other cultivars. Different yields, obtained in two experimental years, may have been due to changing meteorological conditions and to the genetic characteristics of various cultivars and harvesting time (Helgadóttir et al., 2018). In our experiment, cuts were taken at the same time; this is also an important factor for herbage productivity of the perennial ryegrass cultivars. Vegetative persistence that maintains herbage growth and survival without reseeding is an important trait for pasture establishment. Plant vegetative persistence is important; however, there is a deficiency of long-term trials to observe the complex interactions between plant genotype and environment (O'Connor et al., 2020). Over time in a long-term trial, a change in the genetic trait of a cultivar could occur, as plants with genetically enhanced persistence traits survive.

Recent studies have focused on single perennial ryegrass cultivars, but little research has been done on cultivation possibilities and prospects for growing mixtures of perennial ryegrass cultivars (Lowry et al., 2020; Tubritt et al., 2021). The competitive dynamics of the mixture of perennial ryegrass cultivars during the two growing seasons showed more pronounced differences in the $2^{\text {nd }}$ year of sward use. The cultivar mixture showed better growth characteristics compared to perennial ryegrass single cultivars 'Raminta' and 'Verseka'. Important aspects for a more stable yield are cultivar, cultivar mixtures, seasonality and management (Griffith et al., 2016), yet limited knowledge exists on ryegrass competitive interactions

Performance of perennial ryegrass in mixture swards. Many studies show that single-species swards are approximately twice less productive than high-diversity mixtures, and that this difference increases through time (Finn et al., 2018). Plant species diversity in swards is known to increase and stabilize DMY (Komainda et al., 2020). Recently, more attention has been devoted to the sustainability of swards: soil fertility, maintenance of biodiversity and $\mathrm{N}$ cycle. In stockless cropping systems, legumes are the key elements for nutrient cycling, $\mathrm{N}$ supply, soil fertility and crop productivity. Other studies (Crews, Peoples, 2005) that have simultaneously compared the fate of both sources of $\mathrm{N}$ suggest that in rainfed agricultures, crops recover more $\mathrm{N}$ from fertiliser, but a higher proportion of the legume $\mathrm{N}$ is retained in the soil, and $\mathrm{N}$ losses tend not to differ greatly. However, legume $\mathrm{N}$ is generally less susceptible to loss processes than fertilisers. 
It is very important to optimize functional diversity by combining different species characteristics that are well adapted to local growing conditions, because cultivating mixtures of different plants can be one of the sustainable means of increasing agricultural productivity (Tilman et al., 2014). To comprehensively understand the interconnections between DMY, plant cover, plant diversity and soil fertility, more studies should be done to probe into these relations and hence make a decision along this path. In addition to the plant cover-biomass, plant diversity-biomass relationship is essential and complex.

Perennial ryegrass single-species swards maintained productivity in both experimental years like cultivar mixture due to favourable meteorologica conditions in the winter. In multi-species swards, legumes evolved more in the $2^{\text {nd }}$ year of sward use than perennia ryegrass. Functional traits depend on the environmental conditions and affect productivity and stability (Lowry et al., 2020), and certainly it is important to examine functional traits for ecological performance.

\section{The effect of perennial ryegrass single cultivar} and cultivar mixture on crude protein content in herbage. The experiment identified the DMY and crude protein content. Results of the two-year experiment showed that the highest DMY was produced in the sward with white and red clover in interaction with the most productive perennial ryegrass cultivar 'Elena DS'. This mixture also had very good qualitative indicators of crude protein in the $1^{\text {st }}$ and $2^{\text {nd }}$ years of sward use. In multifunctional swards, spring cut is important, as it produces the highest quality yield that can be used for winter forage. The experimental data showed that additional legume species in the mixture increased the total sward yield. Not only the DMY but also its quality is important when cultivating multifunctional swards. The highest DMY was found in the N-fertilised sward of the 'Elena DS'; however, the quality of the sward in terms of crude protein content was significantly lower compared to the swards of different species composition.

Seasonal distribution of perennial ryegrass

herbage. Natural and anthropogenic factors are affecting ecosystems of the swards (Baral et al., 2019). Therefore, their productivity is not stable, and research data shows that it changes due to many factors, the biggest influence of which is the dominance of the most important perennial grass species, fertilisation, meteorological conditions and use.

The seasonal distribution of DMY is also crucial to total herbage annual DMY; however, no matter how much we want to have the most even distribution of sward yield over the season. It is a difficult task, and usually the annual yield is determined by the yield of the first harvest (Lowry et al., 2020). Therefore, it is important to assess the state of the sward of the cultivar mixture at the beginning of vegetation.

The composition of the mixture affects herbage biomass accumulation in various harvests (Elgersma, Søegaard, 2016; Dovrat et al., 2021). It is not difficult to have a satisfactory DMY at the beginning of the season in multi-species swards; however, perennial ryegrass is responsive to abiotic stresses such as adverse climate conditions during the wintertime (Buttler et al., 2019). Winter damage causes not only the loss of ryegrass production at the beginning of the season (Ullmann et al. 2017) but also affects the annual DMY.

In our experiment, tetraploid cultivars of perennial ryegrass, which are often described as more productive and less sensitive to various abiotic stresses and designed for local specific conditions, were used (Griffith et al., 2016 Kemesyte et al., 2017). The growing season in the second year of sward use was 35 days longer than in the first year, and the yields were higher in all treatments. Also, this may have been due to longer vegetation period and more favourable growing conditions.

\section{Conclusions}

A two-year research into the productivity potential of perennial ryegrass cultivars 'Elena DS', 'Raminta' and 'Verseka' grown as single-cultivar cultivar mixture and in mixtures with white and red clover produced the following conclusions:

1. In the $1^{\text {st }}$ year of sward use, there were found no significant differences in the dry matter yield (DMY) between the single cultivars, while significant differences were revealed in the $2^{\text {nd }}$ year. Over the two years, the differences between the cultivars ranged from 0.6 to $1.1 \mathrm{t} \mathrm{ha}^{-1}$
2. There was established no advantage of the cultivar mixture over single cultivar swards; however the differences were insignificant; therefore, perennial ryegrass cultivar mixtures need comprehensive research before being recommended for use in practice.

3 . In both experimental years, the highest annual DMY was produced by the perennial ryegrass cultivar 'Elena DS'. The difference in DMY among the cultivars was as follows: 'Elena DS' was 13\% more productive than 'Raminta', 9\% than 'Verseka' and 7\% than the cultivar mixture. Winters were mild during the experimental period, but drought conditions in the early stage of growth might have affected the yield of the cultivar 'Raminta'. The productivity of the cultivar mixture was variable during the experimental period. Therefore, more results are needed to quantify the functional traits of cultivars and their interactions in mixtures.

4. The DMY of the mixture of cultivar 'Elena DS' with white and red clover was significantly $(6 \%)$ higher compared with that of single cultivar 'Elena DS fertilised with $\mathrm{N}_{15} \mathrm{~kg} \mathrm{ha}^{-1}$. Swards of more diverse species composition are generally characterised by better quality than single-species swards. Moreover, the mixture of 'Elena DS' with white and red clover had better quality, i.e., $5 \%$ higher crude protein content compared with that of the single cultivar swards.

5. The mixture of perennial ryegrass cultivars with white and red clover produced a relatively good DMY; however, it was 16\% lower than that of 'Elena DS' mixture with the legumes. Using $\mathrm{N}_{150} \mathrm{~kg} \mathrm{ha}^{-1}$, the yield of the most productive 'Elena DS' waS $7 \%$ higher than that of the cultivar mixture, $23 \%$ higher than of the mixture with white clover and $11 \%$ higher than of the mixture with white and red clover.

Received 19032021

Accepted 16062021

\section{References}

Baral K. R., Lærke P. E., Petersen S. O. 2019. Nitrous oxide emissions from cropping systems producing biomass for future bio-refineries. Anriculture Ecosyctems and Environment, 283 106576. https://doi.org/10.1016/j.agee.2019.106576

Bothe A., Westermeier F.', wosnitza, A., wiiiner E., Śchum A. Dehmer K., Hartmann'S. 2018. Drought tolerance in perennial ryegrass (Lolium perenne L.) as assessed by two contrasting phenotyping syctems. Journal of $\Delta$ nronomy and Crop Science, 204 (4): 375-389. https://doi.org/10.1016/j.soilbio.2019.01.026

Buttler A., Marionte $\vec{P}$., ivieisser ivi., Guiliaume T., Signarbieux C., Vitra A., Preux S., Mercier G., Quezada J., Bragazza L., Gavazov K. 2019. Drought-induced decline of productivity in the dominant grassland species Lolium perenne $\mathrm{L}$. depends on soil type and prevailing climetic soil type and prevailing climatic conditions. Soil Biology and

Cosentino S. L. Scordia D., Testa G̈., ivionti A. Aiexopouiou Ė., Christou M. 2018. The importance of perennial grasses as a feedstock for bioenergy and bioproducts. Perennial Grasses for Bicenergy and Bioproducts, p. ?-33 https://doi.org/10.1016/B978-0-12-812900-5.00001-1

Crews 1. E., Peopies îi. B. 20005. Can the synchrony of nitrogen supply and crop demand be improved in legume and fertilizer-based agroecosystems? A review Nutrient Cycling in $A$ arreecosyctems, Brazauskas G. Kemesyte v., Stakeviciuite G., Lemeziene $N$. Autopolyploids in fodder grass breeding Brazauskas $G$. 2017. Autopolyploids in fodder grass breeding Research, 15 (4): e0706. https://doi.org $/ 10.5424 / \mathrm{sjar} / 2017154-11357$

Dovrat G., Sheffer E., Landau S. Y., D̃eutch T̃., Goreiik H., Henkin Z. 2021. Can grazing moderate climatic effects on herbage nutritional quality? A grenemy, 11 (4): 700 https://doi.org/10.3390/agronomy11040700

Elgersma A., Søegaara K. LUío. EIrects or species diversity on seasonal variation in herbage yield and nutritive value of seven binary grass-legume mixtures and pure grass under cutting. European Journal of A gronomy, 78: 73-83. https://doi.org/10.1016/j.eja.2016.04.011

Ergon A., Sediaiu Ğ., Kornonen $\bar{Y}$., virkajärvi P., Bellocchi G. Jørgensen M. Østrem L., Reheul D. Volaire'F. 2018. How can forage production in Nordic and Mediterranean Europe adapt to the challenges and opportunities arising from climate hance? European Journal of A nronomy 92: $97-106$. https://doi,org/10.1016/j.eja.2017.09.016

Finger K., Buchmann î̀. 20̂i 5 . Án ecoiogicai economic assessmen of risk-reducing effects of species diversity in managed rasslands. Ecological Economics, 110 : 80 07

Finn $\mathbf{j}$. A. Kirwan $\mathbf{L}$., Connoiiy j., Sebastia ivi. T., Helgadottir A., Baadshaug O. H., Bélanger G., BlackA., Brophy C., Collins R. P., Cop J., Dalmannsdóttir S. Dei'gado I. Ëlgersma A., Fothergill M., Frankow-Lindberg B.E., Ghesquiere A., Golinska B., Golinski P., Grieu P. Gustavsson A-M Höglind M Huguenin-ElieO., Jørgensen M M Kadziuliene Z, Kurki P. Liurba R Lunnan T, Jørgensen M., Kadziuliene Z., Kurki P., Llurba R., Lunnan T., function enhanced by combining four functional types of plant species in intensively managed grassland mixtures: a 3-year 
continental-scale field evneriment Inurnal of $\Delta$ prlied Ecology, 50 :

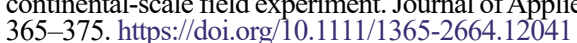

Finn J. A., Suter Mi., Haughey E., Hoter D., Luscher A. 2018. Greater gains in annual yields from increased plant diversity than losses from experimental drought in two temperate grasslands. A griculture Erocystems and Environment, 258 149-153. https://doi.org/10.1016/j.agee.2018.02.014

Foley J., Ramankutty N., Brauman K. A., Cassidy S., Geber J. S., Johnston M., Mueller N. D., Oconell C., Ray D. K., West P. C., Balzer C., Bennett E. M., Carpenter S. R., Hill J., Monfreda C., Polasky S., Rockstrom J., Sheehan J., Siebert S., Tilman D., Zaks D. P. 2011. Solutione for a cultivated nlanet. Nature, 478 : 337-342. https://doi.org/10.1038/nature10452

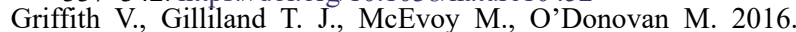
Competitive dynamics in mixtures of perennial ryegrass cultivars during two growing seasons under two cutting managements. Cron and Pasture Science, 67 (2): 225-235. https://doi.org/10.1071/CP15249

Helgadottir Á., Aavola K., İsolahti M., Marum P., Persson C., Aleliūnas A., Brazauskas G., Krisjánsdóttir T. A., Asp T. RognliO. A. 2018. Adaptability and phenotypic stability of Lolium perenne L. cultivars of diverse origin grown at the margin of the species distribution. Iournal of A gronomy and Crop Science, 204 (5): 493-504. https://doi.org/10.1111/jac.12273

Kemesyte V., Statkeviciute G., Brazauskas G. 2017. Perennial ryegrass vield performance under abintic stress. Cron Science, 57: 1935. https://doi.org/10.2135/cropsci2016.10.0864

Komainda M., Küchenmeister $\overline{\mathrm{F}}$., Küchenmeister $\tilde{\mathrm{K}}$., Kayser M., Wrage-Mönnig N., Isselstein J. 2020. Drought tolerance is determined by species identity and functional group diversity rather than by species diversity within multi-species swards. Eurnnean Inurnal of A oronomy 110. 126116.

https://doi.org/10.1016/j.eja.2020.126116

Li X., Petersen S. U.., Sørensen P., Üiesen J. E. 2015. Effects of contrasting catch crops on nitrogen availability and nitrous oxide emissions in an organic cropping system. Agriculture Ecosystems and Environment, 109: 382-393. https://doi.org/10.1016/j.agee.2014.10.016

Lowry C. J., Bosworth S. C., Gosiee S. C., Kersbergen R. J., Pollnac F. W., Skinnerc R. H., Warrene N. D., Smithe R. G. 2020. Effects of expanding functional trait diversity on productivity and stability in cultivar mixtures of perennial ryegrass. Agriculture, Ecosystems and Environment 287: 106601. https://doi.org/10.1016/j.agee.2019.106691

McLonagh J., U U Vonovan M.'., MicEvoy ' Mi., Gilliland T. J. 2016. Genetic gain in perennial ryegrass (Lolium perenne) varieties 1073 to 2013 . Funhytica 212 ar. https://doi.org/10.1007/s10681-016-1754-7

McDonagh J.., Styczen Mi. E.., Miacdonaid A., Piepho H., Honermeier B. 2020. Long-termanalysis from a cropping systemperspective: Yield stability, environmental adaptability, and production risk of winter harlev. European Iournal of A Agronomy, 117: 126056. https://doi.org/10.1016/j.eja.2020.126056

Nekrosas S., Kemesyte V. ZUU\%. Breeding of ryegrass and festulolium in Lithuania. Żemdirbyste-Agriculture, 94 (4): 29-39.
O’Connor J. R., Jahufer M. Z. Z., Lyons T. 2020. Examining perennial ryegrass (Lolium perenne L.) persistence through comparative genetic analyses of two cultivars after nine years in the field. Euphytica, 216 (36): $201-214$.

Porter j. K. Xie L. C̈naiiinor A. j., Cocirane K., Howden S. M. Iqbal M. M., Lobell D. B.,Travasso M.I.,LobelD., B., Travasso M.I'. 2014. Food security and food production systems. Field C. B. (ed.). Climate Change 2014: Impacts, Adaptation, and Vulnerability. Part A: Global and Sectoral Aspects. Contribution of Working Group II to the Fifth Assessment Report of the Intergovernmental Panel on Climate Change. Cambridge University Press, USA, p. 485-533.

Schaub S., Buchmann N., Lüscher A., Finger R. 2020 (a). Economic benefits from plant species diversity in intensively managed grasslands. Ecolegical Economics, 168: 80 07 https://doi.org/10.1016/j. ecolecon.2014.12.019

Schaub S., Finger K., Leiber F., Probst S., Kreuzer M., Weigelt A. Buchmann N., Lorenzen M. 2020 (b). Plant diversity effects on forage quality, yield and revenues of semi-natural grasslands. Nature Communications, 11: 768
https://doi.org/10.1038/s41467-020-14541-4

Schmitz C. . Biewaid A., Lotze-Campen Ḧ., Propp A. Dietrich J. P. Bodirsky B., Krause M., Weindl I. 2012. Trading more food: implications for land use, greenhouse gas emissions, and the food system. Global Environmental Change, 22 (1): 189-209. https://doi.org/10.1016/j.gloenvcha.2011.09.013

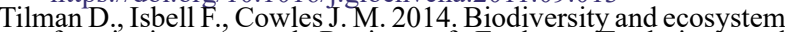
functioning. Annual Review of Ecology, Evolution, and Syctematics, 15: 471-103

https://doi.org/10.1146/annurev-ecolsys-120213-091917

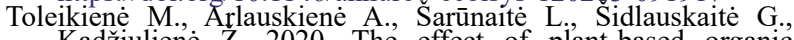
Kadžiuliene Z. 2020. The effect of plant-based organic fertilisers on the yield and nitrogen utilization of spring cereals the organic cropping system. Zemdirbyste-A griculture, 107 the organic cropping system Zemdirbyste-A arreult
(1): $17-24$. https://doi.org/10.13080/z-a.2020.107.003

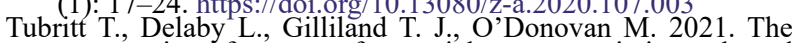
agronomic performance of perennial ryegrass varieties evaluated as single-species crops and mixtures of varying complexity under animal arazins. European Journal of A gronomy, 124:
126226 . https://doi.org $10.1016 / j$.eja.2020.126226

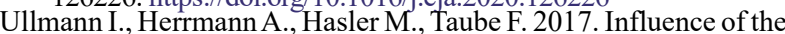
critical phase of stem elongation on yield and forage quality of perennial ryegrass genotypes in the first reproductive growth. http://dor org/10 1016/j fcr 2017 .

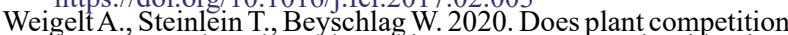
intensity rather depend on biomass or on species identity? Basic Applied Ecology, 3: 85-04.
https://doi.org/10.1078/1439-1791-00080

WRB̉. ¿Ûं4. worid reierence base 1or soii resources. World Soil Resources Reports No. 106. FAO, p. $187-189$.

Yates S Jaškūne K., Liebisch F., Nagelmüller S., Kirchgessner N., Köiliker R., Walter A., Brazauskas G., Studer B. 2019. Phenotyping a dynamic trait: leaf growth of perennial ryegrass under water limiting conditions. Frentiers in Plant Science, 10: 344 https://doi.org/10.3389/fpls. 2019.00344

Zandaiınas î. S., iviititier K., Bairagón D., Arbona V., GómezCadenas A.'2017. Plant adaptations to the combination of drought and high temperatures. Physiclegia Plantarum, 162 (1): $2-12$. https://doi.org/10.1111/ppl.12540

\title{
Daugiametès svidrès trijų tetraploidinių veislių ir jų mišinio produktyvumo potencialas jaunuose žolynuose su dobilais
}

\author{
G. Šidlauskaitè, M. Toleikienè, Ž. Kadžiulienė \\ Lietuvos agrarinių ir miškų mokslų centro Žemdirbystès institutas
}

\section{Santrauka}

Daugiametès svidrès auginamos daugelyje šalių dèl gero derlingumo ir geros kokybès pašaro. Skirtingos veislès turi specifinių funkcinių bruožų, pavyzdžiui, fenologiją, augimo formą ir greitị, turinčių įtakos mišinių konkurencingumui ir produktyvumui. Naujų daugiametès svidrès veislių ar jų mišinių auginimas žolynuose yra viena iš papildomu priemonių siekiant pagerinti žolynu būklę.

Tyrimo tikslas - nustatyti trijų naujesnių, mažiau ištirtų lietuviškų daugiametès svidrès (Lolium perenne L.) veislių 'Elena DS', 'Raminta' bei 'Verseka' ir jų mišinio produktyvumo potencialą vienarūšiuose žolynuose ir mišiniuose su pupiniais augalais - baltaisiais ir raudonaisiais dobilais. Eksperimentas įrengtas Lietuvos centrineje dalyje, nemoralinès klimato zonos sąlygomis.

Mišiniai su pupiniais augalais papildomai nebuvo tręšti; vienarūšiai žolynai tręšti $\mathrm{N}_{150} \mathrm{~kg} \mathrm{ha}^{-1}$ mineralinių trąšų per metus. Per dvejus tyrimo metus gauti daugiamečių svidrių sausųjų medžiagų vidutiniai derliai: veislès 'Elena DS' derlius siekè 8,00 $\mathrm{t} \mathrm{ha}^{-1}$, 'Verseka' - 7,4 $\mathrm{t} \mathrm{ha}^{-1}$, 'Raminta' $-6,9 \mathrm{t} \mathrm{ha}^{-1}$, veisliu mišinio $-7,4 \mathrm{t} \mathrm{ha}^{-1}$. Pirmaisiais žolynų naudojimo metais reikšmingų skirtumų tarp veislių nenustatyta, tačiau antraisiais veislès 'Elena DS' svidrių produktyvumas buvo reikšmingas, palyginus su kitomis veislemis. Veislių funkcinių savybiu itaka buvo reikšminga pirmaisiais auginimo metais ir išliko vienarūšiuose žolynuose, bet ne mišiniuose nuo antrujų metų. Veislès 'Elena DS' svidrès mišinyje leido vystytis dobilams, todèl padidejo žolynų produktyvumas ir žalių baltymų kiekis.

Apibendrinus tyrimo rezultatus galima teigti, kad svidriu veisliụ mišinys gali būti naudingas žolynuose, nes gaunamas derlius panašus su vienos veislès žolynais. Vis dèlto veislių mišinio nauda gali kisti per sezonus, todėl reikia atlikti daugiau tyrimų, kad būtų galima ịvertinti poveikị produktyvumui bei kokybei didèjant žolynų amžiui ir veikiant įvairioms aplinkos sąlygoms.

Reikšminiai žodžiai: baltieji dobilai, daugiametès svidrès, raudonieji dobilai, rūšių įvairovè, sausosios medžiagos. 